\title{
A Fourteen Year Follow-Up Study of Health Promoting Schools in Norway: Principals' Perceptions of Conditions Influencing Sustainability
}

\author{
Hege E. Tjomsland*, Torill Marie Bogstad Larsen, Nina Grieg Viig and Bente Wold
}

University of Bergen, Faculty of Psychology, Research Centre for Health Promotion, Norway

\begin{abstract}
In this study, we examined the sustainability of health-promoting practices in Norwegian schools that were enrolled in the European Network of Health-Promoting Schools from 1993 to 2003. The research questions were: How do the principals perceive that health-promoting practices have been sustained in the schools following the schools' membership of the health-promoting schools network? In what way is school leadership related to the sustainability of health promotion? The study draws on qualitative data consisting of interviews with seven principals in 2008 and school documents. The schools determined their own priorities for action based on assessment of needs in 1994. After 14 years, health promotion practices were sustained in six of the seven schools. Two factors emerged as vital for sustained health promotion practices: the health-promoting school experience and the maintenance and development of practice. The health-promoting school experience relates to staff who internalized the potential link between health promotion practices, school satisfaction, and learning. This also emphasizes the importance of the transfer of experience in sustaining health promotion practices as the staff turned over. The maintenance of vision and practice relates to the principals' commitment to school health promotion, leadership practices that encourage health promotion practices, and external collaboration with the surrounding community in health promotion.
\end{abstract}

Keywords: Health-promoting school, sustainability, leadership.

Schools are increasingly called upon to target health concerns in the student population [1], and many European countries have implemented school policies relating education and health [2]. Although schools are encouraged to implement health promotion actions, few countries provide legislative incentives for schools to embark on such work [3]. Consequently, the development of healthy policies and practices seems to depend primarily on the principals' and teachers' motivation and the perceived need for such practices in schools.

The implementation of healthy policies and practices usually requires some change in teachers' practices and the school curriculum [4]. Research points to complex endeavors to change schools by both ministers of education and principals in their own schools [5]. However, when schools implement change, the change is often not sustained, which implies that the new practice has never become a routine and effortless part of most teachers' practice [6].

The European Network of Health-Promoting Schools (the ENHPS) was a strategic program for the European region that sought to integrate the policy and practice of health promotion into the educational sector (http://www.euro.who.int/ENHPS). The evaluation of the ENHPS may provide valuable knowledge about the integration and sustainability of the health-promoting school in education [7]. The purpose of this study was to examine the sustainability of health promotion practices in the

*Address correspondence to this author at the University of Bergen, Faculty of Psychology, Research Centre for Health Promotion, Norway;

Tel: + 4755988222 / 47782809 06; Fax: + 47555898 87;

E-mails: pspht@iuh.uib.no,heger@tjomsland.cc
Norwegian schools that participated in the ENHPS from 1993 to 2003. It was hypothesized that the sustainability of such practices depends, to a large degree; on school leadership because the literature provides much evidence that the principal is the critical agent in transforming schools [8, 9]. However, there are few data on leadership and management strategies that support sustainable change processes in a health-promoting direction. Hence, principals' perceptions of the degree of sustainable practice and the conditions linked to its sustainability constitute the main part of this study.

\section{THE HEALTH-PROMOTING SCHOOL}

The health-promoting school is increasingly accepted as an effective way of planning, implementing, and sustaining health education in the curriculum $[10,11]$. The healthpromoting school is based on a settings approach, which recognizes that the health and well-being of students and staff are not only a matter of individual choices but are influenced by the context in which students and staff learn, work, and play [12]. Therefore, the health-promoting school attempts to build supportive school environments that promote students' capacity to make healthy choices and to develop positive attitudes and relationships. It is a multifactorial approach, which includes health knowledge and skills, changing the social and physical environment, and creating links with the community [13]. The healthpromoting school approach differs in its overall strategy from what is often referred to as "health education," which involves a set of separate health promotion activities with no health policies or joint effort by everyone in the school [9]. The Council of Europe, the European Commission, and the World Health Organization (WHO) Regional Office for 
Europe established a partnership in 1991 to promote the health of young people in schools in Europe. This partnership resulted in the ENHPS. Today, the network is run as the Schools for Health in Europe (SHE) network, and it is intended to be the European platform for school health promotion (http://www.schoolsforhealth.eu/). The SHE network is coordinated by the Netherlands Institute for Health Promotion and Disease Prevention, the WHO Collaborating Centre for School Health Promotion. It provides information, encourages research, shares good practice, expertise, and skills, and advocates school health (http://www.schoolsforhealth.eu).

\section{SUSTAINABILITY}

The distribution of health promotion programs involves innovation development, dissemination, adaptation, implementation, and maintenance [14]. "Maintenance" refers to the sustainability of an innovation, and a health-promoting school should be set up in such a way to ensure that positive changes are sustained and embedded in the school's operation [15]. However, studies of innovations in the educational setting suggest that the multitude of ideas targeting schools and the complexity of many programs challenge sustainable change processes [16]. In this study, the "sustained aspects" of the health-promoting school refer to the formalization of relevant policies on health promotion practices (healthy eating, physical activity promotion, dealing with bullying, and school satisfaction). It reflects the integration by teachers of health promotion practices into the daily fabric of school life. The sustenance of aspects of the health-promoting school implies that health promotion has become part of the school's core values and normal way of working.

The health-promoting school can be considered to represent a school improvement initiative because it seeks to develop and integrate policy and practice taken from the health and education sectors to achieve better health and educational outcomes. "School improvement" refers to sustained changes in learning conditions and other internal conditions, with the ultimate aim of achieving educational goals more effectively [17].

\section{LEADERSHIP PRACTICES}

Successful school improvement depends on a school's capacity to manage change and development [18, 19], and good leadership, either by the principal or other teachers, seems central to building a capacity for organizational change [6,9]. Leithwood, Harris, and Hopkins [20] suggest that leadership is about improving the performance of teachers, which is again a function of the teachers' beliefs, values, motivations, skills, and knowledge, and their working conditions. If principals motivate teachers so that they have the "will" and the "capacity" to carry out the recommended changes, school reform and change are more likely [21]. Studies of educational leadership and evidence from nonschool organizations point to four broad categories of basic leadership practice: building visions and setting directions, understanding and developing people, designing the organization, and managing the teaching and learning program [21-23].
Teachers may feel challenged by imposed goals and practices [24]. Therefore, it is vital to build shared visions and directions in school health promotion. Møller, Eggen, and Fuglestad et al. [25] suggest that students' learning is the focal point of both the philosophy and practice of Norwegian schools. The recognition by teachers of improvements in student learning has been identified as the main reason why teachers' change their practice [26]. Thus, to implement and sustain health promotion visions and practices, it is reasonable to involve teachers in joint reflections about the positive outcomes of school health promotion. If teachers see the connection between students' health and well-being and their educational achievements, they may, as Fullan [21] suggests, develop collective meanings related to the benefits of health promotion, which again may lead to an integration of health promotion into the school's daily fabric. Leithwood, Harris, and Hopkins [20] suggest that, when the direction is widespread, it is less vulnerable to leadership successions. Given that school health promotion is not always compulsory, health promotion practices that are not deeply rooted in the teaching staff may be particularly vulnerable to a shift in leadership.

The second basic leadership practice refers to understanding and developing people [23]. In terms of health promotion practices, it is reasonable to assume that the empowerment of teachers in health promotion contributes to its sustainability. A former case study by the ENHPS suggested that the constant desire of teachers to improve and learn in the promotion of physical activity contributed to the sustenance of physical activity practices [27]. Hence, it seems important that the principal delegate responsibilities and opportunities to learn according to the competence and interests of the teachers. For instance, teachers with no interest in the promotion of physical activity will probably more positively sustain health promotion practices if they are assigned responsibilities and opportunities in other areas of the health-promoting school.

Collaborative practices in school may be central to school improvement [28], and designing the organization refers to building collaborative cultures and creating structures that support collaboration and productive working relations [23]. Jones and Eick [24] suggest that innovative schools often have a network of partnerships with organizations and agencies in the public and private sectors. The ENHPS also points to collaboration within the school and between the school and the outside community as essential ingredients of health promotion practice [29]. It seems likely that partnerships in health promotion may bring new ideas and competence into a school and thus contribute to its sustainability. They may also apply some pressure to teachers to retain health promotion practices.

The final leadership practice refers to managing the teaching and learning program [23]. Through management, a leader translates guiding ideas into practice by establishing plans and schedules to achieve specific results $[30,31]$. In school health promotion too, management skills related to building relationships, providing information, influencing people, and decision making are vital [22]. For instance, if a school aims to implement more physical activity, the principal may benefit from building relationships with community sport teams, organizing openings in the timetable 
for more physical activity, and recruiting teachers with physical education competence, to achieve the school's aim.

A principal may also choose to delegate management responsibilities to other teachers. Distributed leadership is most commonly described as the roles undertaken by teachers, who have both management and pedagogical responsibilities, such as developing curriculum materials or being subject coordinators [19]. School programs often use a teacher in a leadership position to act as the program coordinator, collaborating with staff in implementing a program or practice. Deschesnes, Martin, and Hill [32] suggest that the person in charge of school health promotion ought to have leadership, management, and evaluation skills. Another study by the ENHPS found that the implementation of the health-promoting school benefited from program coordinators who were either part of or collaborated closely with the leader group [33].

This study places school leadership as the central factor in change. Therefore, the principals' reflections about aspects of sustained health-promoting practice (vision, curriculum, and actions) and the factors related to its sustainability or lack of sustainability were examined in the network of Norwegian health-promoting schools. The research questions were as follows.

- $\quad$ How do the principals perceive that health-promoting practices have been sustained in the network schools following the schools' membership of the healthpromoting schools network?

- In what way do leadership practices contribute to the sustainability of health promotion practices in the network schools?

\section{METHODOLOGY}

Sample

Description of the Norwegian schools enrolled in the ENHPS. Forty Norwegian schools applied for membership of the ENHPS after a letter of invitation from the Ministry of Education was sent to all (approximately 3000) elementary and junior high schools in the country. The 10 schools admitted to the program varied in size and were located in rural and urban regions of the country. The Norwegian part of the ENHPS was organized as a school wide program (1993-2003), supposedly involving all staff members. Either the principal or a teacher, preferably one from the leader group, acted as the program coordinator, with specific responsibilities in health promotion. The health-promoting school emphasized students' well-being and confidence rather than a narrower concept of health. Each school adopted unique premises upon which individual health promotion practices were developed: physical activity promotion, healthy eating, supportive social environments, and the development of curricula that included health promotion were central elements [34]. All 10 schools were members of the network until the final meeting in 2003. The program coordinator and a member of the leader group in each school participated in this meeting.

The support of the principal was crucial to the implementation of health promotion practices [9]. Therefore, it was assumed that the principals' support for health promotion also influenced its sustainability. It also seemed likely that a person in the leader group had the best general view of the school's vision and practice, and for that reason the principals were invited to be interviewed. Seven principals were positive about participating, whereas

Table 1. Profiles of Schools

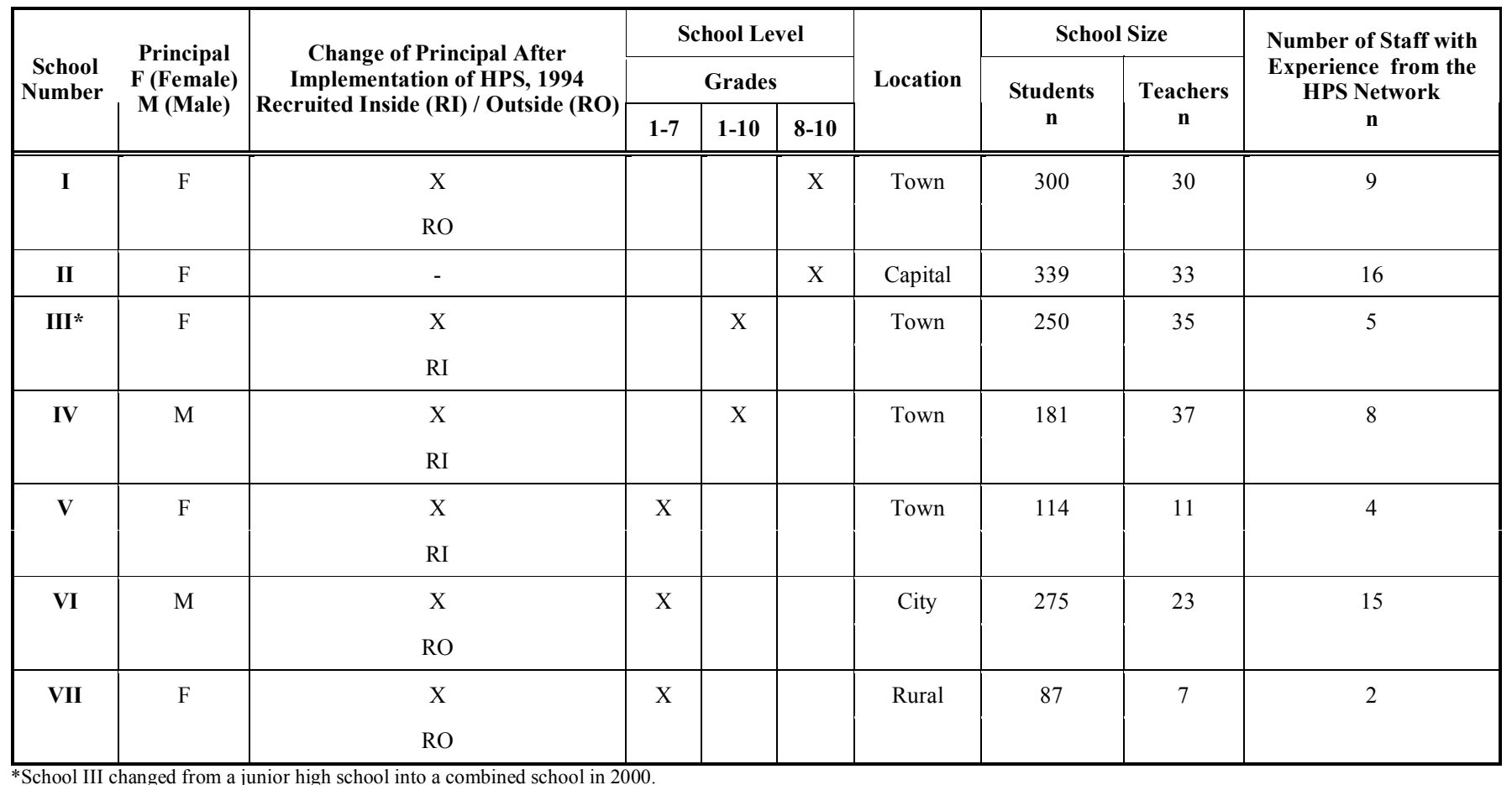


three principals did not respond to the request. In school I, the principal asked her male inspector to take her place as the informant because of time constraints. In the other schools, the principals themselves participated. In presenting the findings, all the informants are referred to as "principals."

\section{Instruments}

School documents. A university center for health promotion collected the school documents during the network period of 1993-2003. This documentation, combined with survey data at the student level from 1994 to 1998 , informed the writing of individual evaluation reports to the schools in 2001 (document 1). The documents analyzed here also include structured seminar notes (document 2). Strategy plans, vision plans, and developmental plans from 2008 (documents 3-8) were also studied (see Table 2).

An interview guide was developed based on Leithwood and Day's strategies related to successful principal leadership: building shared visions and directions, developing and understanding people, designing the organization, and managing the teaching and learning programs [23]. Former studies of the Norwegian network also influenced the development of the interview guide [33]. The key questions concerned the schools' current work with health-promoting practices, the principals' perceptions of the reasons for health-promoting practices in school, and their reflections about the leadership strategies that facilitated or inhibited sustained health-promoting practices.

\section{Data Collection}

School documents. Documents 1 and 2 were provided by the university center and documents 3-8 were collected from the schools' Web sites or through e-mail correspondence with the school leaders in 2008. Descriptive data for all the schools in 2008 were found on the schools' Web sites.

Interview data. The interviews were performed on the telephone by the first author in March 2008. They lasted from 30 minutes to one hour during the school day. All the principals agreed to the recording of the interviews.

\section{Data Analysis}

The documents listed in Table $\mathbf{2}$ were read several times. First, the evaluation reports describing the developments within each school were studied to provide information about the schools' aims and practices. Second, the documents were studied to assess whether health promotion had been written into plans and curricula. Third, the documents from 2007/08 were studied to look for information that expanded or contradicted the interview data. The findings from the school documents are numbered doc.\# to provide a link with the specific document.

The interview data. Following the case study methods of Yin [35], the analysis of the interview data was guided by a review of the literature and the research questions that informed the study. The interview transcripts were read and reread, and the information was labeled with codes associated with the main issues in the interview guide. Next, similar codes were grouped into categories and subcategories. The qualitative data analysis software package QSR N7 (http://www.qsrinternational.com) was used. The analysis was an iterative process that involved going back and forth between the data, the manuscript preparation, and discussions among the coauthors. The final step involved going back to the literature related to innovations in schools and school leadership to compare and contrast the findings with previous findings [36].

\section{Validation of the Accuracy of the Findings}

This study presents the principals' perceptions of sustained health promotion practices and the visibility of health promotion in school documents. The principals' assessments of sustained health promotion practices may differ from the perceptions of other members of the school community. However, the comparison of the interview data and the school documents adds strength to the interview data. The analysis was also discussed by the coauthors and any discrepancies in understanding were resolved through discussion. Finally, the network coordinator at the university center read and commented on the manuscript.

\section{RESULTS}

\section{Sustained Health Promotion Practices}

In 2008, 14 years after the "health-promoting school" approach was introduced into schools in Norway, six of seven principals reported that health promotion practices had been sustained and further developed. School documents showed that schools I, II, III, IV, and V referred to aspects of health promotion in their vision statements or as priority areas in 2007/08 (see Table 3).

Table 2. School Documents

\begin{tabular}{|l|l|c|}
\hline$\#$ & \multicolumn{1}{|c|}{ Documents } & \multicolumn{1}{|c|}{ Year } \\
\hline \hline 1 & Individual evaluation reports to the schools written by a university center for health promotion & 2001 \\
\hline 2 & Structured notes from the final HPS - meeting written by one of the co-authors & 2003 \\
\hline 3 & Developmental plan 2007-2008, school I & 2008 \\
\hline 4 & Strategic plan 2008-2011, school II & 2008 \\
\hline 5 & Vision statement, school II & 2008 \\
\hline 6 & Developmental plan, 2006-2008, school III & 2008 \\
\hline 7 & Vision statement, school IV & 2008 \\
\hline 8 & Curriculum plan, 2007-2008, school V & 2008 \\
\hline
\end{tabular}


Table 3. Vision Statements and Priority Areas Described in School Documents

\begin{tabular}{|c|l|}
\hline School & \multicolumn{1}{|c|}{ Vision Statements / Priority Areas $\mathbf{2 0 0 7}$ - 2008 } \\
\hline \hline I & $\begin{array}{l}\text { A school for life: develop students' self competence and wish to accelerate. Provide knowledge and experiences that } \\
\text { increase the students' total competence. Continue to increase students' physical activity levels through various activities } \\
\text { during the school day. Make physical activity a compulsory part of teaching. Include students' in promoting physical } \\
\text { activity. Make the students more conscious related to healthy foods. Offer a student run cafeteria with healthy products. }\end{array}$ \\
\hline II & Our priority area is the health-promoting school: health, sports, culture, computer technology \& internationalization. \\
\hline III & $\begin{array}{l}\text { Good health: Achieve good health and a healthy lifestyle for all in school. } \\
\text { We have the opportunity to and we are obliged to develop safe and health promoting social and physical environments. }\end{array}$ \\
\hline IV & $\begin{array}{l}\text { Health and activity: we facilitate for high levels of physical activity and healthy foods. } \\
\text { We emphasize a good social environment for students and staff. }\end{array}$ \\
\hline V & $\begin{array}{l}\text { Our school is a health-promoting school with extended focus on healthy foods, physical activity, outdoor school and } \\
\text { the mixing of age groups }\end{array}$ \\
\hline
\end{tabular}

Health promotion was not currently a priority area at school VI or part of its vision. However, the principal argued that practices related to school satisfaction, the management of bullying, physical activity, and outdoor schooling were integrated into the fabric of the teachers' daily practice and the school's action plan. A school document (document 1) shows that these areas were given priority at the commencement of the program, in particular the management of bullying and physical activity promotion.

(School VI) The priority areas from the healthpromoting school, like school satisfaction, bullying, and physical activity, are still vital features in school. We work with school satisfaction continuously and we have worked a lot with physical activity, outdoor schooling, and bullying. So I consider this as sustained aspects of the work during the 90s. If you look back, much of our current work is also in the plans from 1994. A priority area usually covers three years, but we do not stop working with it after that. Physical activity has, for instance, been a priority area many times. It is in our action plans, so we do not need to note it as a priority area continuously.

The other principals also reported aspects of health promotion that were neither priority areas nor formalized in curriculum plans because they had been built into ongoing use and organizational structures.

(School I) There are events and practices, such as our welcome party, that we do not write into plans because it is in the walls. However, when we again focus on school satisfaction and physical activity, like we did during the healthpromoting school, or more precisely we increase our focus because we have always focused on this, then we need to write it into our developmental plan. In this way, we involve all teachers, not just the interested ones.

\section{Conditions Influencing Sustained Practices, as Perceived} by the Principals

Two factors emerged as vital to the sustainability of health promotion: the health-promoting school experience and the maintenance and development of practice (see Fig. 1).

The health-promoting school experience. All principals, except the principal of school VII, referred to the health-promoting school experience as central to their current health promotion practices.

(School III) I am sure that it would have been problematic to choose good health as a priority area if we had not worked a lot with this during the health-promoting school. Good health did not just happen out of the blue; it was a result of our network experience and new leaders.

(School VI) One reason why we emphasize health and school enjoyment is that many of the teachers who worked here during the healthpromoting school still work here and they understand that it is necessary and important.

(School VII) When I talked to the former school leader, he said that the health-promoting school experience was the most important thing he had been involved in during his 30 years as a principal.

The health-promoting school program coordinators expressed similar views at a seminar in 2003 (document 2). The coordinator in school I stated: "Our school is newborn, and the midwifery was the health-promoting school," and the coordinator at school VI stated: "The health-promoting school did something to our school and those who work there," (document 2).

Based on the categories that emerged from the data analysis, the health-promoting school experience seemed to consist of two subthemes, which relate to the health 


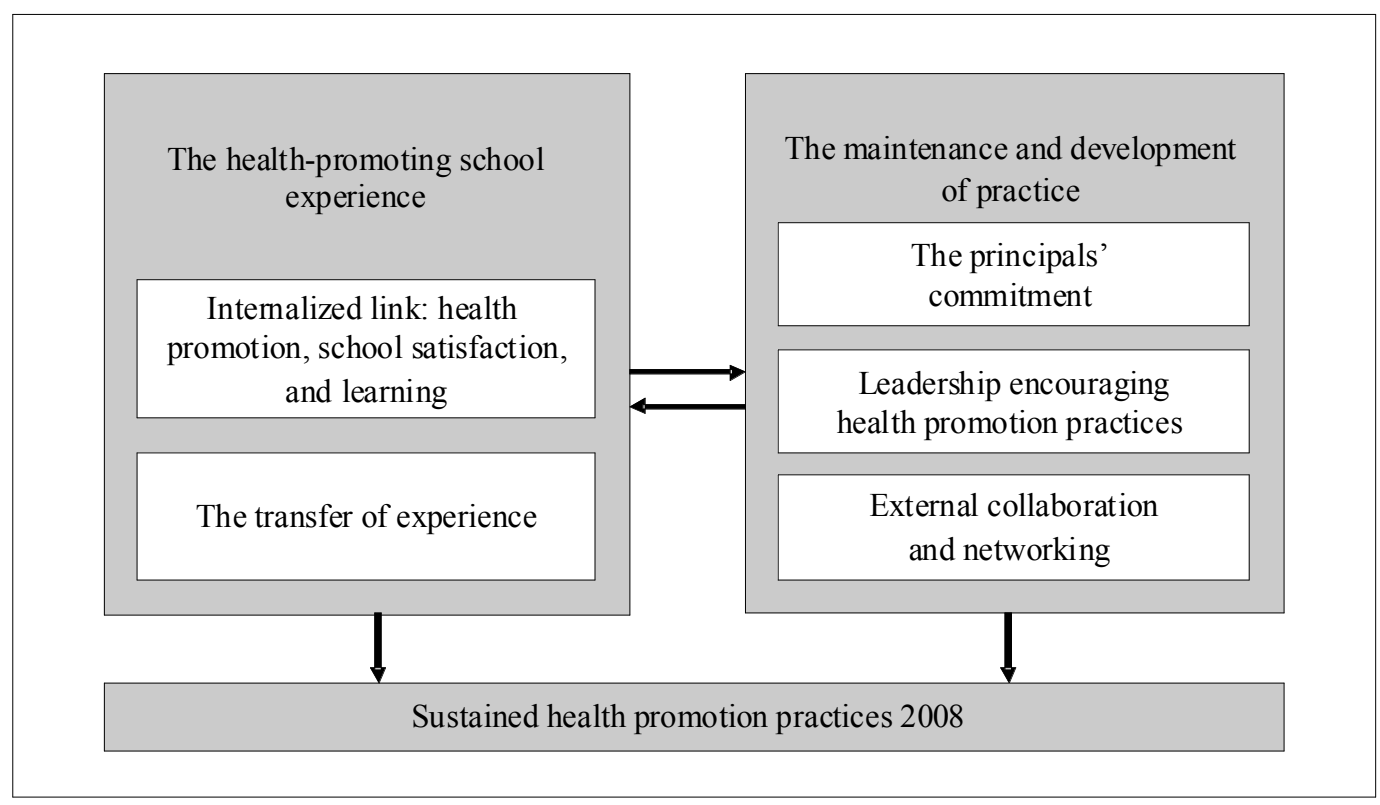

Fig. (1). Causal network of findings.

promotion practices internalized by the staff and the transfer of experience to new teachers (see Fig. 1). First, the healthpromoting school experience had, according to the school leaders, contributed to making the staff more aware of the link between health promotion practices, students' school satisfaction, and learning. The health-promoting school experience had increased their awareness of how physical activity promotion, healthy foods, restriction of bullying, and cultural activities were part of an overall focus on school satisfaction. Students' school satisfaction was perceived as a basis for academic achievement.

(School III) We emphasize students' school satisfaction. The students ought to enjoy school and feel good here. It is fundamental to learning, and it involves physical activity, cultural activities, and healthy meals.

(School VI) School satisfaction and safety are at the bottom of this school. It is under the teachers' skin and in our walls. We work with this no matter what is on our agenda.

The principals of schools I and II also reported that, through the health-promoting school experience, the staff had internalized an attitude that embraced the whole individual student, and therefore sought mastery rather than failure.

(School I) Those who participated in the healthpromoting school experience have school satisfaction "beneath their skin." I think that goes for the other teachers too because we are the eldest and we are the most experienced and so on. So the attitude towards students, students' worth, is the most visible characteristic of this school.

Secondly, the transfer of experience seems to have been vital in sustaining the school's experience in health promotion because there had been repeated turnovers of staff. The experience in health promotion was, according to the principals, transferred informally among the staff from teachers with experience in health promotion to newcomers. School V also applied more formal strategies to the transfer of experience insofar as new teachers were introduced to the school's pedagogical platform and health promotion practices on student-free days at the beginning of each new semester.

There had been a change of principal in all but one school since the establishment of the network. Yet, both the internally and externally recruited new principals valued their schools' experience in health promotion. The four externally recruited principals shared their schools' values relating to health promotion and school satisfaction, and, apart from the principal of school VII, all believed that they contributed to their schools' progress in health promotion.

(School VI) I share the school's values. I worked with health and school satisfaction in my former school, and I think that it must be at the basis of a school. So that is partly why I applied for a job here. I knew that school satisfaction and health were ingrained here.

According to the current principal of school VII, the previous principal's retirement after 30 years had affected the sustainability of health promotion practices. The new principal expressed a very positive attitude towards health promotion and she had had a lot of experience, particularly in physical activity promotion. However, she perceived no transfer of experience in health promotion from the former school principal, and she believed that health promotion practices were not part of the daily fabric of her teachers' professional lives. She also reported a lack of formalization of the vision and practices in the school's plans and a lack of competence and interest in her teachers.

(School VII) The former principal was a visible and confident leader. A lot of things depended on him. So I feel that I don't get any response. 
They do not seem to understand that I depend

on them. It is as if they wait for me to act.

Maintaining and developing vision and practice. The maintenance of vision and practice was the second factor that emerged as vital to the sustainability of health promotion. Here, the principals demonstrated commitment to the school's health promotion, applied management that encouraged health promotion practices, and collaborated externally in health promotion.

First, the principal's commitment emerged as vital to the sustainability of health promotion.

(School IV) The principal is important. If he or she does not support a priority area, it will not succeed.

(School VI) If the leader group does not believe in health promotion, the health-promoting focus may rapidly change into something else.

All principals signaled their commitment to health promotion practices, despite the current pressure for academic accountability in response to Norwegian students' poor results on international school tests. The principals maintained health promotion practices because they recognized the positive outcomes of such practices. At school I, for instance, the principal was excited about how increased opportunities for physical activity outdoors led to student interactions across grades and age groups and therefore to an improved social environment. At schools II and III, the principals related the reduction in vandalism and student absenteeism to their health promotion practices. The principal of school II reported that she and her staff had sustained their sports profile and cultural emphasis because they perceived that it prevented racism in their multicultural student group. The principal of school $\mathrm{V}$ referred to a very positive learning environment and students who concentrated and were capable of enduring the long school day as a result of health promotion practices. The principal of school VI attributed the lack of bullying and the enjoyment of school by students to the health promotion practices that were central to this school.

(School I) If you focus on both academic results and school satisfaction, and if a positive student attitude is rooted in the school, then you find solutions to most challenges. If the students, for instance, enjoy themselves during physical activity, the result is a better school day. When the students get rid of energy in daily physical activities, the teachers spend less time managing problematic student behavior.

(School II) Norwegian, math, English, and sciences are all that matter now. But we can't work like that because we have many academically poor students. We need to focus on the whole individual. All schools should do that.

(School III) Our school is situated in an area that does poorly on surveys related to living conditions. Thus, it is important to give our students common experiences related to physical activity and healthy meals because they may not eat breakfast or bring lunch. They don't have skies and have not even tried skiing. Some have never been on hiking trips and haven't experienced barbequing in the countryside. It is vital to keep in mind what students and teachers you have when making visions and plans. Now we have found something that is good for us, and, interestingly, our exam scores have improved in the past years.

(School V) There is a push now on academic results and test scores, but we know that it must be entwined with physical activity and healthy meals.

Second, the principal's leadership supported the sustainability of health promotion. Even if health promotion practices seemed to be integral to a school's core values, they were constantly developing and changing. All schools, except school VII, reported regular pedagogical discussions among the staff and evaluations of the health promotion practices. In school III, health-promoting events were first assessed in staff meetings and then documented in writing. The teachers were also encouraged to report daily physical activity on the school's Web site. The principals believed that the documentation and formalization of the experience in the curriculum and activity plans facilitated future health promotion practices, and stimulated the transfer of experiences by making them less vulnerable to turnovers in staff. The principals of schools I, III, and IV perceived that once health-promoting practices had been written into the curriculum, the teachers were more committed.

(School III) We have annual, monthly, and weekly activities, which we always evaluate, even if it is only a trip to the ski lift in walking distance from here. All activities are formalized in writing. As such, we have updated "receipts" for all events.

(School IV) For us, the leader group, and even for the county, it is vital to have "the house" (a visualization of the school's pedagogical platform used in communication with teachers, parents, and politicians) as the basis of our practice because it commits the teachers. Even the parents have contributed in developing this platform. It is supposed to be at the core of our thinking and practice. We are currently discussing whether we should develop an action plan for each room in this house, with specific aims and dates, so we constantly evaluate and reflect on our platform. With this house as the basis, teachers can't run private practices like before.

The principals perceived teacher competence as a criterion for the success of sustained health promotion practices. They believed that motivated teachers were central to maintaining health promotion as part of the schools' daily lives. Therefore, it was important that they understood and developed teacher initiatives in health promotion. At school IV, for instance, one teacher's particular interest and competence in outdoor schooling led to an increased focus 
on the outdoors. The teachers were also empowered in health promotion through distributed leadership. At school V, the teacher in charge of physical activity was about to retire. Therefore, the principal provided training for another teacher in physical activity to empower her to take on the responsibilities of physical activity after the current coordinator retired. At school II, in contrast, the principal facilitated distributed leadership through a reduction in teaching obligations. She also deliberately looked for teachers that matched the school's vision and practice when employing staff.

(School IV) It is important to involve teachers who are interested in order to have some innovators in the system. When teachers are excited and suggest things, they should have the opportunity to implement their ideas.

(School V) I try to make my teachers responsible, and then I include them from day one when we have decided on something new ... there is room for trying and failing.

Three principals reported differences in teacher involvement and the strategies that they used to build collaborative teacher groups for health promotion. At school IV, the principal used his right to make the final decision when staff disagreed. At school VI, the principal highlighted good practices by setting an example, whereas the principal of school III used her annual "coworker conversations" as a place to deal with a lack of follow-up related to health promotion practices. She said she listened to the teachers and made an effort to understand why they did not get involved in health promotion practices. The key to future involvement, according to her, was a capacity to build new assignments in health promotion.

(School IV) If staff disagrees, the principal must make the final call and say: this is how it will be. It is not a problem. Most people are loyal.

(School VI) There is no disagreement related to health and school satisfaction, but there are differences related to how much staff prioritizes health promotion and how well they prepare. No teachers resist it, but some teachers do not pay much attention to it and do not make an effort. We approach this by paying attention to it and making the best practices visible. When some teachers do a great job organizing our winter physical activity week, then we makes certain that all teachers take notice and we say "look how great this is" and we ask "why were they successful?" Well, it probably went well because they did this and this and this. That is my style, rather than telling people that they are not doing their jobs.

(School III) It is important to formalize good health in plans and to apply a combination of support and pressure to the staff. I need to set aside time and say that, in this particular week, we'll emphasize good health. Simultaneously, it is important to integrate good health into our daily life. So I follow up daily and I confront teachers directly, for instance in coworker dialogues if a teacher does not prioritize it. I don't need to do that often, but I do it because a teacher cannot ignore a priority area. It mainly involves talking together and understanding each other because there are different reasons why teachers do not get involved. Sometimes they feel incompetent, and then we may agree on professional training or reassignment of tasks and responsibilities. We have different talents and, accordingly, not all teachers feel comfortable with, for instance, physical activity promotion.

Third, networking and collaboration contributed to the maintenance and further development of health promotion practices. The principals of schools III, IV, V, and VI organized collaborations with other schools in their regional networks to promote physical activity and healthy meals. These networks were led by teacher training colleges or county health promotion coordinators.

(School V) It is rewarding to participate in networks. This year, our students will climb 10 mountain peaks. We are in the middle of doing this, and the students truly enjoy it. We were inspired to do this by other schools in the physical activity network. Networking is about making each other better and about learning from schools with the same emphasis.

At school II, international collaboration with other European health-promoting schools was emphasized. At the final meeting in 2003, the principal of school II stated that "the ENHPS is a universal key to other schools in Europe," (document 2), and for 10 years school II had collaborated with a health-promoting school in the Netherlands.

The schools reported collaborations in health promotion with external partners to various degrees, including with community sport teams, school nurses, the police, parents, and a local farm. At school IV, the principal referred to a culture of sports in the community, including external support from health promotion coordinators in the township and the county. He believed that "community expectations" in combination with physically competent staff and the expectations of students encouraged sustained health promotion practices. The principals of schools I, V, and VI also referred to governmental action plans that instructed schools to develop positive school environments and to increase physical activity promotion in their schools.

(School I) When governmental instructions for more physical activity are launched, these instructions must be reflected in our plans. However, we were already working with physical activity before the governmental emphasis.

(School VI) When you ask why we conduct work related to health and school satisfaction, the answer is that it is part of the national plans. The national curriculum instructs us to work with students' health and school satisfaction. 


\section{DISCUSSION}

All but one of seven principals reported sustained health promotion practices in relation to healthy eating, physical activity promotion, management of bullying, and school satisfaction. The principals perceived that their schools had visions, policies, or developmental areas in place in line with the health promotion aims that had been formulated in 1994. The principals stated that aspects of the health-promoting school had been sustained over time in their organizations. Internal evaluation reports confirm that the practices cited by the school leaders in 2008 had been initiated at the start of the program (document 1).

However, the principals' comments reflect that healthpromoting practices influenced the everyday lives of the schools in different ways. Whereas the principals of schools IV and VI referred to specific practices embedded in school life on a regular basis, such as weekly and monthly sporting or cultural events, the other principals were more concerned with how health promotion influenced the everyday lives of the teachers and students. For example, at schools I and II, the principals primarily emphasized that the healthpromoting school experience had developed an attitude in the staff such that they embraced the students as whole human beings, requiring opportunities for development outside the academic classroom. The principals of schools III and $\mathrm{V}$ were also explicit on this aspect of the healthpromoting school, but they were equally clear on how the experience had structured physical activity promotion, healthy eating, outdoor schooling, and school satisfaction in the daily life of the school community. At school V, health promotion seemed to be fully integrated into the teachers' daily practices, as expressed in the school's vision statement: "We are a health-promoting school...." A case study of school V showed that health promotion did not have a special project status but had become integral to the school's fabric [27]. The differences in the development and integration of health promotion are also reflected in the internal evaluation reports (document 1). Here, some schools were described as having implemented the health-promoting school approach as specific activities and special projects, whereas other schools had adopted the health-promoting school as an overall concept reflecting their pedagogical platforms and daily practices. The three schools that did not reply to the request for an interview were classified in the evaluation reports as having either low or moderately integrated health promotion practices (document 1). Hence, the principals' lack of interest in participation in this study may reflect how health promotion had been embedded in their school life during the network period.

The health-promoting school experience emerged as a central component affecting the sustainability of health promotion practices. Program implementation in schools often consists of preplanned lessons and a teacher manual, although it is recognized that teachers often do not fully implement programs according to a prepackaged design [37]. Empowerment is an essential strategy in health promotion [38], and the schools in the Norwegian network were guided in health promotion by a university center. Follow-up by professionals seems to have played a key role in building positive experiences among the staff. The university center communicated regularly with the schools and arranged biannual seminars for a couple of teachers and leaders in each school to empower them in terms of systematic planning, needs assessment, policy development, and evaluation [9]. The seminars also provided opportunities for collaboration between schools in the network with similar interests and priorities [34]. The central elements in the staffs' health-promoting school experience seem to have evolved around the creation of commitment and shared visions of health promotion, and a systematic development of practice, together with competence building in health promotion and the facilitation of collaborative practices within and between schools. The health-promoting school experience seems to have been associated with Leithwood and Day's categories of leadership in schools: building visions and setting directions, understanding and developing people, designing the organization, and managing the teaching and learning programs [27].

Fullan [21] suggests that change processes in schools are more likely to be implemented and sustained if the new curricula or methods are close to the teachers' existing working methods and values. When the health-promoting school was implemented in Norway, the central components in the national curriculum were the social learning environment and teacher collaboration [39]. Therefore, when it was introduced in Norway, the health-promoting school probably did not deviate greatly from the staffs' existing values and practices because the schools probably had some experience of activities that aimed to improve the psychosocial environment of students, before becoming involved in the network. Viig and Wold's study [33] suggested that Norwegian teachers perceived that the healthpromoting school helped them fulfill the goals of the national curriculum. If teachers and principals believed that health promotion practices contributed to their educational mission, such perceptions may have underpinned the building of shared health promotion visions and the creation of positive experiences.

The principals' commitment and leadership was initially predicted to be the central factor influencing the sustainability of health promotion practices in schools [9], and 14 years after the program was implemented the school principals reported that they were still committed to health promotion practices, despite a recent governmental emphasis on academic accountability and results-driven curricula. Datnow [6] suggests that a change in district and state policies may affect the sustainability of school reform, and it seems likely that the recent market orientation in Norwegian schools could have pushed school enjoyment issues to a peripheral position [25]. However, the principals seemed to have internalized the relationship between health, school satisfaction, and learning. To them, health promotion practices contributed positively to the schools' teaching and learning programs, and, therefore, external pressures regarding test scores are not perceived as working against health promotion but rather as yet another incentive.

The principals reported that time was earmarked for pedagogical discussions and critical reflections among the staff, related to where they wanted to go and how they wanted to get there in terms of health promotion. Fullan [21] argues that purposeful interactions among staff related to change are essential for continued school improvement. 
Senge [40] suggests that a leader should point to where the organization wants to be, but at the same time be realistic about where the organization is. By building and reinforcing shared visions and aspirations for health promotion [23], the principals established collaborative cultures, which mitigated teachers' loss of interest in the field and the abandonment of established practices.

School improvement efforts are often abandoned during a change in school leadership [6]. Nevertheless, five of the six new principals reported having sustained and further developed these health promotion practices. Accordingly, the schools' visions and experiences in health promotion seemed to be deeply ingrained in the school and were transferred even at the leadership level. Statements such as "it is in the walls," "under the teachers' skin," and "at the basis of the school" indicate that health promotion practices have become taken-for-granted features in these schools. The experience was passed on informally from experienced teachers to new teachers or through formal management strategies; building and reinforcing visions, the formalization of plans, the creation of structures to support health promotion, the staffing of schools with teachers well matched to the health promotion priorities, and teacher development. Accordingly, these principals do much of what Leithwood and Day suggest that successful leaders do in the four categories of basic leadership practices [23].

Health promotion practices were aborted in only one school during a change in leadership. However, it seemed to be the former principal's leadership rather than the new principal's lack of commitment to health promotion that led to the abandonment of health promotion. The current principal referred to the former principal as a visible and perhaps somewhat authoritative leader. Unlike the other principals, he had not delegated leadership in health promotion. The new principal also referred to a teacher group that lacked enthusiasm and energy. Hence, the combination of a dominant leader and a rather inactive teacher group seems to explain, in part, why health promotion was not embedded in the structures and norms of this school.

Yukl [22] argues that efforts to implement change in an organization are more likely to be successful if the leader understands the reasons for resistance to change. Two principals reported teachers who hesitated to become involved in health promotion, and one principal suggested that teachers' unwillingness was often related to a lack of competence. Thus, she tried to understand each teacher's interests and qualifications in order to design an organization with room for various preferences and responsibilities in health promotion, and to offer capacity building to support individual staff. Hence, her leadership demonstrates what Leithwood and Day refer to as understanding and developing people [23].

The principals moreover facilitated external collaboration in health promotion both locally, nationally, and internationally. Senge [40] suggests that schools that improve in sustainable ways depend on surrounding districts and communities. Because the leader position can be lonely, the principals themselves may have experienced networking as particularly rewarding because it provides an arena for professional interaction. As a whole, the principals developed, as Leithwood and Day suggest, productive working relations that allowed staff to make the most of their motivations and capacities in health promotion [23].

\section{LIMITATIONS AND CONCLUSIONS}

This study was primarily based on principals' perceptions, and the principals may have introduced bias in reporting favorable pictures of their schools. The inclusion of students and teachers in the study would have provided a more nuanced picture of the activities of each school. Nonetheless, it is important to understand the principals' views because they play a key part in making health promotion an integral part of their organizations. Given that the school documents support the interview data, the principals' perceptions seem truthful.

Kichbush [12] suggests that evaluations of health promotion from a settings approach do not fit easily into an epidemiological framework of evidence. The healthpromoting school approach allows each school a degree of autonomy in the development of the program [13]. Therefore, it is challenging to develop universal indicators that reflect the status of health promotion in the individual schools [7]. Case-specific indicators are required to identify the complex processes involved in introducing health into the school organization [38]. Future evaluations of the health-promoting school approach will probably benefit from case studies that are sensitive to the context of the everyday life of the school, which defines the health of students and staff.

\section{ACKNOWLEDGEMENTS}

This research was supported by grants from the Norwegian Foundation for Health and Rehabilitation through the National Committee for Public Health. We also thank Assistant Professor Oddrun Samdal, the Norwegian national coordinator for the European Network of Health Promoting Schools, for valuable contributions to the acquisition of data and for comments on the manuscript.

\section{REFERENCES}

[1] Davidson FF. Childhood obesity prevention and physical activity in schools. Child Obes Prev 2007: 107(4): 377-95.

[2] Clift S, Jensen BB. In: Clift S, Jensen B, Ed. The health promoting school: international advances in theory, evaluation and practice. Copenhagen: Danish University of Education Press 2005.

[3] Hardman K, Marshall J. In: Green K, Hardman K, Eds. Physical education in schools in European context: charter principles, promises and implementation realities, in physical education essential issues. London: Sage Publishers 2005; pp. 39-64.

[4] Morrison MH, Kitson JN, Wortley A. Joined-up thinking in theory and practice: the case of healthy schools? Curriculum J 2002; 13(3): 313-37.

[5] Caldwell B J. A strategic view of efforts to lead the transformation of schools. Sch Leadersh Amp Manag 2004; 24(1): 81 - 99.

[6] Datnow A. The sustainability of comprehensive school reform models in changing district and state contexts. Educ Adm Q 2005; 41(1): 121-53.

[7] Barnekow VB, Clift S, Jensen BB, Paulus P, Rivett D, Young I. Health-promoting schools: a resource for developing indicators. The WHO Regional Office for Europe, the European Commission and the Council of Europe: Copenhagen 2007.

[8] Day C, Leithwood K. Successful principal leadership in times of change: an international perspective. Dordrecht: Springer 2007; vol. IX: p. 203s.

[9] Samdal O. In: Heggenhougen HK, Quah S. Eds. School Health Promotion in International Encyclopedia of Public Health. San Diego: Academic Press 2008; pp. 653-61. 
[10] Fiona R, Donald S, Carla P. Promoting school connectedness through whole school approaches. Health Educ 2007: 107(6): 524.

[11] Dooris M. Healthy settings: challenges to generating evidence of effectiveness. Health Promot Int 2006; 21(1): 55-65.

[12] Kickbusch I. The contribution of the world health organization to a new public health and health promotion. Am J Public Health 2003; 93(3): 383-88.

[13] Stewart-Brown S. What is the evidence on school health promotion in improving health or preventing disease and, specifically, what is the effectiveness of the health promoting schools approach? health evidence network report. WHO Regional Office for Europe: Copenhagen 2006.

[14] Oldenburg B F, Hardcastle D, Kok G. Diffusion of health education and health promotion innovations. In: Glanz K, Lewis BF, Rimer B, Eds. Health behavior and health education: theory, research and practice, San Francisco: Jossey-Bass 1997; pp. 31234.

[15] Gray G, Young I, Barnekow V. Developing a health-promoting school. A practical resource for developing effective partnerships in school health, based on the experience of the European Network of Health Promoting Schools, The WHO Regional Office for Europe: Copenhagen 2006.

[16] Dowda M, Sallis J F, McKenzie T L, Rosengard P, Kohl H W. Evaluating the sustainability of SPARK physical education: a case study of translating research into practice. Res Q Exerc Sport 2005; 76(1): 11-19.

[17] Reynolds D, Teddlie C, Hopkins D, Stringfield S. Linking school effectiveness and school improvement. In: Teddlie C, Reynolds D, Eds. The international handbook of school effectiveness research. London: Routledge Falmer 2001; pp. 206-32.

[18] Muijs D, Harris A. Teacher led school improvement: teacher leadership in the UK. Teach Teach Educ 2006; 22(8): 961-72.

[19] Muijs D, Harris A. Teacher leadership in (In) action: three case studies of contrasting schools. Educ Manage Adm Leadersh 2007; 35(1): 111-34

[20] Leithwood K, Harris A, Hopkins D. Seven strong claims about successful school leadership. Sch Leadersh Manage 2008; 28(1): 27-42.

[21] Fullan M. The new meaning of educational change, $4^{\text {th }}$ ed. New York: Teachers College Press 2007; p. 338

[22] Yukl GA. Leadership in organizations. Upper saddle river. NJ: Pearson/Prentice Hall 2005.

[23] Leithwood K, Day C. Starting with what we know. In: Day C, Leithwood K, Eds. Successful principal leadership in times of change: an international perspective. Dordrecht, The Netherlands: Springer 2007; pp. 1-13

[24] Jones MT, Eick CJ. Implementing inquiry kit curriculum: obstacles, adaptations, and practical knowledge development in two middle school science teachers. Sci Educ 2007; 91(3): 412-3.
[25] Møller J, Eggen J, Fuglestad O L, et al. Successful leadership based on democratic values. In: Day C, Leithwood K, Eds. Successful principal leadership in times of change: an international perspective. Dordrecht, The Netherlands: Springer 2007; pp. 71-83.

[26] Guskey T R. Professional development and teacher change. Teach Teach 2002; 8(3): 381-91

[27] Tjomsland H, Larsen T, Samdal O, Wold B. Sustaining comprehensive physical activity practice in elementary school: a case study applying mixed methods. Teach teach 2008;. in press.

[28] Clayton C D G, Schoonmaker F. What holds academically able teachers in the profession? A study of three teachers. Teach Teach 2007; 13(3): pp. 247-67.

[29] Gray G, Young I, Barnekow V. Developing a health-promoting school. A practical resource for developing effective partnerships in school health, based on the experience of the european network of health promoting schools. The WHO Regional Office for Europe, the European Commission and the Council of Europe: Copenhagen 2006

[30] Senge PM. The leader's new work: building learning organizations. Sloan Manage Rev 1990; 32(1): 7.

[31] Daft RL. The leadership experience. South-Western Canada: Thomson 2005.

[32] Deschesnes M, Martin C, Hill A J. Comprehensive approaches to school health promotion: how to achieve broader implementation? Health Promot Int 2003; 18(4): 387-96.

[33] Viig N G, Wold B. Facilitating teachers' participation in schoolbased health promotion - a qualitative study. Scand J Educ Res 2005; 49(1): 83-109.

[34] Wold B, Samdal O. Health promotion among young people: the development of healthy school environments. Dissemination of experiences from the norwegian schools in the European network of health promoting schools. Bergen: University of Bergen, Research Center for Health Promotion 1999.

[35] Yin R. Case study research. $2^{\text {nd }}$ ed. London: Sage Publications 1994.

[36] Creswell J W. Research design. Qualitative, quantitative and mixed methods approaches. $2^{\text {nd }}$ ed. London: Sage Publications 2003.

[37] Angela S, Karen G. Factors influencing teachers' implementation of an innovative tobacco prevention curriculum for multiethnic youth: project SPLASH. J Sch Health 2008; 78(5): 264.

[38] Rootman I. Evaluation in health promotion: principles and perspectives. Copenhagen: World Health Organization Europe 2001.

[39] Imsen G. Lærerens verden. Innføring i generell didaktikk. (Teachers' world. An introduction to didactics) $3^{\text {rd }}$ ed. Oslo: Universitetsforlaget 2006

[40] Senge P M. Schools that learn. London: Nicholas Brealey 2000

This is an open access article licensed under the terms of the Creative Commons Attribution Non-Commercial License (http://creativecommons.org/licenses/bync/3.0/) which permits unrestricted, non-commercial use, distribution and reproduction in any medium, provided the work is properly cited. 